\title{
KONSTRUKTOVÁ VALIDITA BOCHUMSKÉHO OSOBNOSTNÍHO DOTAZNÍKU: MOTIVAČNí DIMENZE
}

\author{
JAN KuBA ${ }^{1,2}$
}

\begin{abstract}
Abstrakt: Cílem studie bylo ověřit konstruktovou validitu motivačních dimenzí Bochumského osobnostního dotazníku (inventáře profesních charakteristik osobnosti). $V$ teoretické části byly definovány související osobnostní konstrukty, které byly v empirické části využity $k$ ověrení odvozených motivačních dimenzí. Kvantitativní data byla získána na vzorku 778 studentů a absolventů vysokých škol. K ověrení konstruktové validity bylo využito konfirmatorních faktorových analýz, na jejichž základě byl vytvořen strukturní model ilustrující podobu vztahů mezi zkoumanými dimenzemi. Byly nalezeny dílčí doklady konstruktové validity motivačních dimenzí Bochumského osobnostního dotazníku.
\end{abstract}

Klíčová slova: Bochumský osobnostní dotazník, konstruktová validita, motivace $k$ výkonu, motivace $k$ vedení, motivace $k$ utváření, svědomitost, dominance, sensation seeking, selfefficacy

Abstract: The aim of the study was to verify construct validity of motivational dimensions of the Czech version of the Business-Focused Inventory of Personality. Personality constructs linked to derived personality dimensions were defined in the theoretical part of the study. Quantitative data were obtained using the sample of 778 university undergraduates and graduates. Confirmatory factor analyses were used in order to explore construct validity of the method. Structural model based on the factor analyses was created to outline relations among the examined dimensions. Partial evidence on construct validity of the method was found.

Key words: Business-Focused Inventory of Personality, construct validity, achievement motivation, motivation to lead, need for power, conscientiousness, sensation seeking, dominance, self-efficacy

\footnotetext{
${ }^{1}$ Katedra psychologie, Fakulta sociálních studií MU, Joštova 10, 60200 Brno

2 Your Solution, s.r.o., Hněvkovského 65, 61700 Brno
} 


\section{Teorie}

Bochumský osobnostní dotazník (BIP) je metodou německých autorů Rüdigera Hossiepa a Michaela Paschena, který vzniká nepřetržitě již od 90. let. BIP měří celkem 14 pracovních charakteristik rozdělených do 4 dimenzí; profesní orientace, pracovní chování, sociální kompetence a psychická konstituce. Cílem BIP je komplexně pojmout pracovní chování, jednání i zvyky testované osoby. Proces tvorby a validizace metody byl veden požadavky diagnostické praxe, BIP tak není dostatečně zakotven v související teorii. Předmětem studie jsou 3 škály dimenze profesní orientace (motivace $k$ výkonu, vedení a utváření) z aktuálního druhého českého vydání z roku 2011 (Hoskovcová \& Vybíralová, 2011).

Škála Motivace k výkonu (MVý) má své teoretické zázemí v konstruktu potreby výkonu (Need for Achievement) Davida McClellanda (1987a, 1987b), který ji pojímá jako připravenost vyrovnávat se s vysokými měřítky a snahu průběžně měřit a zvyšovat své výkony. Vztah MVý a Svědomitosti je zdokumentován v mnoha studiích (McCrae \& Costa, 1987; Richardson \& Abraham, 2009). Taktéž vztah MVý, Svědomitosti a školního prospěchu (O`Connor \& Paunonen, 2007). Z pětifaktorového modelu osobnosti (Big Five) je to právě Svědomitost, která se zdá být nejvíce provázána s MVý $(r=0,24)$, jak ve své rozsáhlé metaanalytické studii potvrdili Judge a Remus (2002). MVý je zkoumána taktéž ve vztahu k Self-efficacy (Aliverini \& Lucidi, 2011). Silný vztah mezi MVý a Self-efficacy $(r=0,44)$ byl nalezen také ve studii provedené Eliasem, Noordinem a Mahyuddinem (2010). Na základě syntézy současných zjištění lze předpokládat silný vztah Motivace výkonu se škálami Self-efficacy a Svědomitost.

Motivace k vedení (MVe) má své teoretické základy v McClellandově (1987b) potřebě moci (Need for Power), kterou konceptualizoval jako př́mý vliv na sociální pochody. MVe je považována za základní determinantu leadershipu (Oh, 2012) a jejich prediktory jsou často zkoumány společně, někdy i ztotožňovány (Stacey, David, Jeewon, \&Soo, 2008). Při hledání prediktorů MVe (či specificky leadershipu) bývá za jeden z hlavních označována dominance (Hills, 1985; Rueb \& Foti, 1990; McCormack \& Mellor, 2002). Dominantnější jedinci měli v průběhu experimentu ve zkoumaných modelových situacích větší tendenci zaujímat vůdčí postavení (Rueb, Erskine, \& Foti, 2008), byt' samotný vztah zkoumaných dimenzí byl slabý $(r=0,16)$. Z tohoto důvodu by měla být i Motivace k vedení (BIP) v pozitivním vztahu s Dominancí (16 PF, Cattell, Cattell, \& Cattell, 1997).

Motivace k utváření (MU) je poslední a zároveň nejkomplikovanější zkoumanou dimenzí. Podobně jako MVe nalézáme její teoretický základ v McClellandově konceptu potřeby moci (McClleland, 1987a; McClelland, 1987b). McClelland předpokládá, že potřeba moci má podobu bud' personální (ta se vztahuje k MVe) nebo institucionální. Právě institucionální potřeba moci je základem škály MU a lze ji definovat jako potřebu ovlivňovat procesy a struktury (McClelland, 1987b; McClelland \& Boyatzis, 1982). S obsahovým pojetím škály nejlépe koresponduje dimenze Boredom Susceptibility (BS), která je součástí rysu Sensation Seeking Marwina Zuckermana (1971). Přítomnost rysu 
Boredom Susceptibility lze chápat jako jedincovu rezistenci vůči opakujícím se podnětům (Kirchner, 2012; Zuckerman, 1979; Zuckerman, 1994). BS odkazuje zejména k intelektovým výzvám, tendenci aktivně vyhledávat nové zážitky a být aktivním činitelem dění (Zuckerman, 1979), což svou charakteristikou dobře odpovídá pojetí MU v BIP. Přestože autorovi textu není známa studie, která by daný vztah ověřovala, lze na základě uvedených skutečností předpokládat souvislost MU a BS. Zároveň na základě uvedených informací lze předpokládat, že MU bude $\mathrm{v}$ silném pozitivním vztahu s dominancí (16 PF).

Následující schéma zobrazuje souvislosti osobnostních faktorů a motivačních škál Profesní orientace tak, jak jsou předpokládány na základě teoretické analýzy.

Schéma č. 1: Předpokládané souvislosti mezi měřenými proměnnými

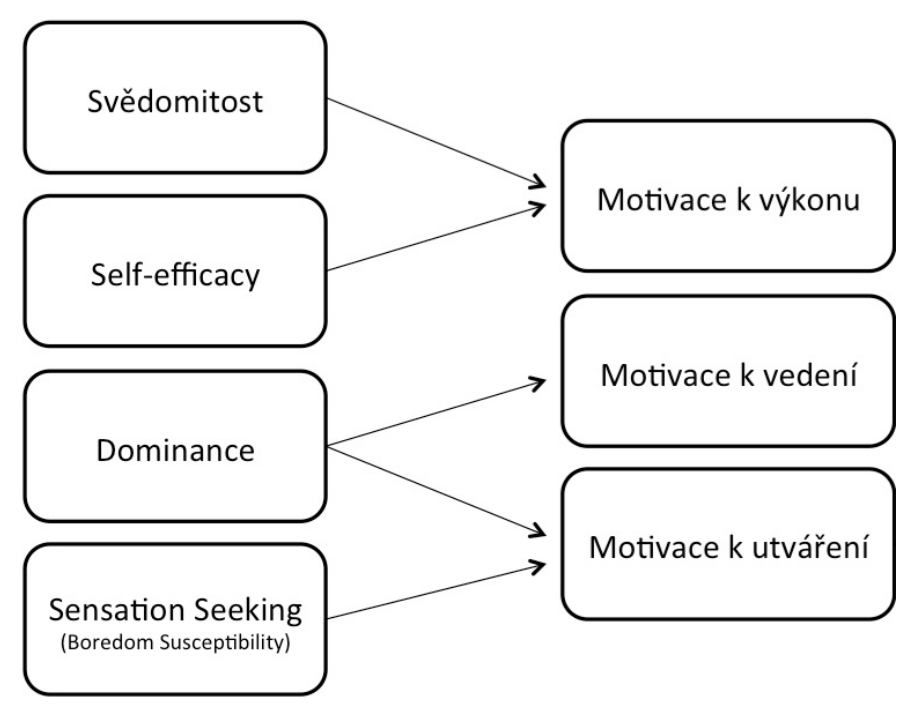

\section{Metody}

Jednotlivé dimenze všech diagnostických metod byly převedeny do elektronického prostředí a formou anonymního online dotazníku (vyplnto.cz) bylo osloveno přibližně 2000 vysokoškolských studentů s žádostí o participaci na výzkumu.

Cílovou populací byli studenti VŠ a čerství absolventi VŠ, kteří jsou méně než 1,5 roku od ukončení studia, nebot' tato populace nejlépe odpovídá diagnostickým záměrům BIP (Hoskovcová \& Vybíralová, 2011). Do sběru dat se zapojilo 1279 osob. Do analýz bylo zahrnuto celkem 778 (61 \%) respondentů, kteří vyplnili dotazník kompletně. Vyřazeni byli všichni respondenti, kteří nevyplnili dotazník celý (z toho více než 70 \% nevyplnilo ani jednu položku a pouze do dotazníku vstoupili). Dále byli vyřazeni ti respondenti, kteří nesplňovali předpoklady pro participaci ve výzkumu - jednalo se absolventy VŠ, kteří překračovali lhůtu 1,5 roku od ukončení studia. Z celkového počtu participantů ( $N=778$ ) bylo 523 žen (67 \%) a 255 mužů (33 \%). Průměrný věk respondenta je 24 let $(S D=3,16, M=23,00 M d n=22,00)$. Tabulka č. 1 shrnuje zastoupení dle oborů ve výzkumném souboru. 
Tabulka č. 1: Zastoupení dle oborů ve výzkumném souboru

\begin{tabular}{lcccccc}
\hline \multirow{2}{*}{ Obor } & \multicolumn{2}{c}{$\begin{array}{c}c \\
(N=778)\end{array}$} & \multicolumn{2}{c}{$\begin{array}{c}\text { žen } \\
(n=523)\end{array}$} & \multicolumn{2}{c}{$\begin{array}{c}\text { mužů } \\
(n=255)\end{array}$} \\
\hline Společenské vědy & 278 & $(35,7)$ & 216 & $(41,3)$ & 62 & $(24,3)$ \\
Ekonomické obory & 138 & $(17,7)$ & 86 & $(16,4)$ & 52 & $(20,4)$ \\
Technické obory & 102 & $(13,1)$ & 24 & $(4,6)$ & 78 & $(30,6)$ \\
Př́rodní vědy & 70 & $(9,0)$ & 54 & $(10,3)$ & 16 & $(6,3)$ \\
Lékařství & 60 & $(7,7)$ & 45 & $(8,6)$ & 15 & $(5,9)$ \\
Právo & 51 & $(6,6)$ & 29 & $(5,5)$ & 22 & $(8,6)$ \\
Ostatní & 79 & $(10,2)$ & 69 & $(13,2)$ & 10 & $(3,9)$ \\
\hline
\end{tabular}

Měřeno bylo celkem sedm osobnostních dimenzí pomocí pěti diagnostických metod. Tři motivační dimenze BIP (celkem $41+10$ položek) ${ }^{3}$, svědomitost z baterie NEO-PI-R (12 položek), dominance z Cattelova 16faktorového dotazníku (10 položek), Self-efficacy s pomocí General Self-efficacy Scale (10 položek) a konečně Boredom Susceptibility ze škály Sensation Seeking Scale (10 položek). Respondenti tedy celkem odpovídali na 93 položek.

K základním analýzám byl využit software SPSS. Strukturní model vztahů motivačních faktorů BIP a osobnostních faktorů byl vytvořen v programu LISREL.

\section{Výsledky}

Tabulka č. 2 obsahuje průměr, směrodatnou odchylku, minimální a maximální dosažené hodnoty a také vnitřní konzistenci vyjádřenou s pomocí Cronbachovy alfy. Vnitřní konzistence všech dimenzí dosahují uspokojivých hodnot a odpovídají hodnotám doporučeným $\mathrm{v}$ manuálech př́ślušných metod. Rozložení zkoumaných osobnostních dimenzí je přibližně normální. Nezávislost rozptylu (homoskedascita) byla taktéž ověřena u všech měřených dimenzí.

Zkoumané dimenze BIP mezi sebou silně korelují ${ }^{4}$ Tabulka č. 3 shrnuje korelační matici všech měřených dimenzí. Tučně jsou zvýrazněny ty korelace, které lze na základě představené teorie očekávat.

\footnotetext{
${ }^{3}$ Kontrolní položky pro škálu Motivace k utváření.

${ }^{4} \mathrm{Na}$ vysokou interkorelaci škál BIP upozorňují i autoři metody (Hoskovcová \& Vybíralová, 2011).
} 
Tabulka č. 2: Popisné statistiky měřených dimenzí

\begin{tabular}{lccccc}
\hline & $M$ & $S D$ & Min & Max & $\alpha$ \\
\hline Svědomitost & 31,8 & 7,5 & 4 & 48 & 0,849 \\
BS & 2,57 & 1,77 & 0 & 9 & 0,510 \\
Motivace k výkonu & 40,1 & 9,9 & 11 & 69 & 0,820 \\
Motivace k utváření & 32,0 & 7,3 & 5 & 54 & 0,681 \\
Motivace k vedení & 34,4 & 11,9 & 3 & 67 & 0,877 \\
Self-efficacy & 19,7 & 4,94 & 0 & 30 & 0,867 \\
Kontrolní MU & 26,5 & 7,57 & 4 & 49 & 0,817 \\
Dominance & 6,18 & 2,23 & 0 & 10 & 0,655 \\
\hline
\end{tabular}

Tabulka č. 3: Korelace měřených dimenzí

\begin{tabular}{lcccccccc}
\hline & SVE & BS & MVy & MU & MVe & SEF & kMU & DOM \\
\hline SVE & 1,000 & & & & & & & \\
BS &,- 104 & 1,000 & & & & & & \\
MVy & $\mathbf{4 1 3}$ &, 167 & 1,000 & & & & & \\
MU &, 155 &, $\mathbf{2 9 7}$ &, 521 & 1,000 & & & & \\
MVe &, 187 &, 295 &, 383 &, 538 & 1,000 & & & \\
SEF & $\mathbf{3 4 9}$ &, 136 & $\mathbf{4 1 4}$ &, 422 &, 428 & 1,000 & & \\
kMU &, 145 &, $\mathbf{2 8 6}$ &, 457 & $\mathbf{, 5 9 7}$ &, 528 &, 467 & 1,000 & \\
DOM &, 211 &, 259 &, 390 & $\mathbf{, 5 0 5}$ & $\mathbf{6 4 7}$ &, 360 & $\mathbf{4 6 5}$ & 1,000 \\
\hline
\end{tabular}

Poznámka: Korelace větší než 0,059 jsou statisticky významné na hladině pravděpodobnosti $\alpha \leq 0,05$, korelace větší než 0,083 na hladině $\alpha \leq 0,01$.

Nad rámec očekávaných korelací je z tabulky č. 3 zřejmé, že struktura vztahů je mnohem komplexnější a složitější, což vyžaduje další zkoumání. Kurzívou jsou vyznačené další silné korelační vztahy, které nebyly na základě související teorie očekávány.

Pro další postup byla zvolena série konfirmatorních faktorových analýz, ze kterých byl vytvořený model, který dobře reflektuje postavení jednotlivých dimenzí (a reflektuje implikované vztahy latentních osobnostních konstruktů na základě manifestních položek jednotlivých škál). V první konfirmatorní analýze byla ověřena struktura motivačních aspektů BIP (proměnné vstupovaly do analýzy jako nezávislé). Stejným způsobem byla ověřena i struktura primárních osobnostních dimenzí. Bylo využito parametrického řešení metodou odhadu maximální věrohodnosti. Na základě dvou 
konfirmatorních faktorových analýz byl sestaven strukturní model, který zobrazuje schéma č. 2.

Schéma č. 2: Strukturní model měřených proměnných

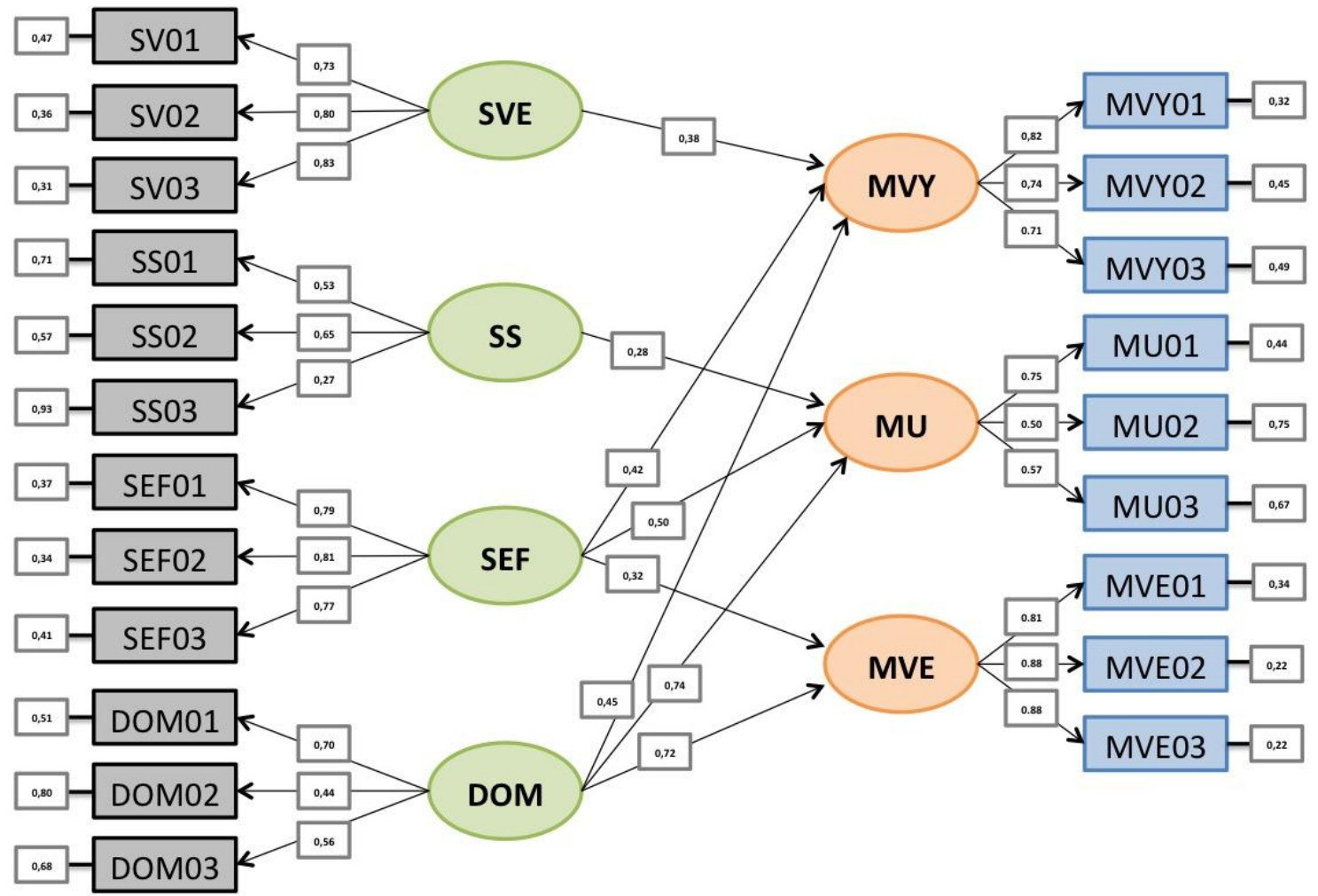

Chi-Square $=602,79, \mathrm{df}=136, \mathrm{P}$-value $=0,00000, \mathrm{RMSEA}=0,066$

Manifestní proměnné jsou $\mathrm{v}$ modelu kódovány stejně jako související latentní konstrukty. Každá manifestní proměnná je rozdělena na tři pod-proměnné a její číslo odpovídá průměru 1., 2., a 3., třetiny položek, ze kterých se manifestní proměnná skládá.

Výsledný model poměrně uspokojivě odpovídá datům: $\chi^{2}(136)=602,79, N=778$, $p<0,000$, RMSEA = 0,066. Byt' je hladina statistické významnosti hodnoty chí-kvadrátu neuspokojivá (což lze v tomto případě z části přičíst početnému výzkumnému souboru), model odpovídá všeobecně přijímanému kritériu, kdy hodnota $\chi^{2}$ nepřesahuje počet stupňů volnosti více než pětkrát (Urbánek, 2000). Hodnota indexu RMSEA též odpovídá obecně přijímaným normám (tamtéž).

Z modelu je patrné, že MVý je vysoce závislá od faktoru DOM $(\beta=0,45 ; p<0,05)$, SEF $(\beta=0,42 ; p<0,05)$ a SVE $(\beta=0,38 ; p<0,05)$. Zároveň je patrné, že SVE jako latentní faktor pro účely BIP vhodně diferencuje a neovlivňuje další měřené motivační aspekty.

MU je nejsilněji odvozena $\mathrm{z}$ faktoru $\operatorname{DOM}(\beta=0,74 ; p<0,05)$, silně je ovlivněna také faktorem SEF $(\beta=0,50 ; p<0,05)$ a slabší (byt' stále významný) vliv na MU má také 
faktor BS $(\beta=0,28 ; p<0,05)$. Latentní faktor BS podobně jako SVE vhodně diferencuje a signifikantně neovlivňuje další motivační aspekty.

MVe je stejně jako predchozí dimenze nejvíce odvozena z DOM $(\beta=0,72, p<0,05)$ a slaběji ze SEF $(\beta=0,32 ; p<0,05)$. DOM i SEF silně ovlivňují všechny měřené motivační dimenze BIP.

\section{Diskuse}

Základní předpoklady byly pomocí strukturního modelu potvrzeny. Motivace $\mathrm{k}$ výkonu se skutečně jeví jako faktor částečně závislý na svědomitosti a self-efficacy. Vliv má také faktor dominance, který silně působí na všechny tři motivační aspekty. Provázanost motivace k výkonu a dominance může být daná také obecným trendem společnosti, kde jsou projevy dominantního chování spojovány s vedoucí pozicí (Hoskovcová \& Vybíralová, 2011; Butt \& Fiske, 1968b). Osobnostní faktor Self-efficacy pak dotvář́ vztah motivace $\mathrm{k}$ výkonu a dominance. Vědomí vlastní účinnosti lze považovat za jeden z předpokladů motivace $\mathrm{k}$ výkonu (Rotter, 1989).

Osobnostní faktor svědomitost v kontextu motivačních faktorů BIP diferencuje dobře. Má dostatečnou inkrementální validitu, nebot' nemá žádné neočekávané vztahy s dalšími motivačními faktory BIP. Na základě tohoto zjištění lze konstatovat, že motivaci k výkonu má smysl měřit zejména s pomocí položek, které jsou postaveny na latentním faktoru svědomitosti a díky tomu dobře diferencují.

Potvrzený byl taktéž předpoklad, že osobnostní faktor dominance je v silném pozitivním vztahu s motivací k vedení a motivací k utváření. To lze považovat jako empirický doklad jejich společného teoretického ukotvení (McClelland, 1987a; McClelland, 1987b). $\mathrm{K}$ diferenciaci mezi těmito (do jisté míry podobnými) faktory dobře přispívá faktor Boredom Susceptibility, od kterého se částečně odvíjí motivace k utváření. Motivace $\mathrm{k}$ vedení však nikoli.

Nad rámec těchto popsaných vztahů vyplynulo i několik neočekávaných. Self-efficacy i dominance jsou $v$ silném pozitivním vztahu se všemi škálami profesní orientace. Jedním z možných vysvětlení může být zjištění, že reálná míra dominance jedince do značné míry souvisí s jeho skutečným postavením v hierarchii společnosti (Hoskovcová \& Vybíralová, 2011; Butt \& Fiske, 1968b). Lze tedy předpokládat, že lidé s vyšší výkonovou motivací (MVy) budou na vyšších postech ve společenské hierarchii; ti se tedy budou projevovat více dominantně, nebot' vyšší pozice umožňují (nebo dokonce podporují) dominantní chování.

Podobně jako je tomu u motivace $\mathrm{k}$ vedení, bylo by vhodné skrze modifikaci položek snížit silný vliv dominance a self-efficacy, které nedostatečně diferencují mezi všemi motivačními aspekty, a najít vhodný konstrukt $\mathrm{s}$ potřebnou diferenciální validitou. Tímto konstruktem by mohla být např́ílad přívětivost (jako samostatná dimenze NEO-PI-R), u které lze předpokládat negativní vztah s motivací $\mathrm{k}$ vedení. Zároveň 
z teoretické části práce vyplynulo, že přívětivost nemá žádný vztah s motivací k výkonu (Hart, Stasson, Mahoney \& Story, 2007), což lze považovat za dílčí doklad diferenciální validity.

Pro další zkoumání by bylo vhodné zaměřit se na nalezení dalších faktorů, které pomáhají diferencovat mezi motivací k vedení a motivací k utváření.

\section{Závěry}

Potvrdily se základní předpoklady konstruktové validity motivačních aspektů BIP. Souvislost latentního osobnostního rysu svědomitost a motivační dimenze výkonnosti a dále souvislost latentního osobnostního rysu dominance a Self-efficacy s motivačními aspekty uplatňování vlivu vůči lidem, procesům a strukturám.

Na základě provedené studie lze usuzovat, že škály motivace k vedení (MVe) a motivace k utváření (MU) jsou aspekty latentního osobnostního faktoru dominance. Provedené studii se podařilo odhalit pouze jeden faktor, který napomáhá mírné diferenciaci. Tímto faktorem je Boredom Susceptibility (BS) ze škály Sensation Seeking, který spoluutváří motivaci k utváření.

Motivace $\mathrm{k}$ výkonu (MVy) je z větší části kombinací vědomí vlastní účinnosti (SEF) a svědomitosti (SVE), což lze považovat za uspokojivé zjištění, které dobře koresponduje s požadavky diagnostické praxe. Menší měrou ovlivňuje MVy i faktor dominance, který plošně působí na všechny motivační aspekty BIP. Toto zjištění je potřeba podrobit dalšímu zkoumání a ověřit, do jaké míry dominance souvisí s Motivací k výkonu; popřípadě do jaké míry máme co do činění s artefaktem metody či samotného měření.

V kontextu metody BIP se jedná o obohacení poznatků a rozšíření znalostní báze. Zároveň se jedná o závěry, které mají praktické implikace př́mo pro diagnostickou praxi i pro možné vylepšení motivačních dimenzí z hlediska obsahu položek. Navazující výzkum v dané oblasti by měl najít další faktory, které dopomohou oddělit Motivaci k vedení a Motivaci k utváření, čímž zjednoduší (a zpřesní) prováděné interpretace. V neposlední řadě je vhodné zaměřit se na reformulaci položek takovým zpơsobem, který by snižoval plošný vliv latentního faktoru dominance. 


\section{Literatura}

Alivernini, F., \& Lucidi, F. (2011). Relationship between social context, self-efficacy, motivation, academic achievement, and intention to drop out of high school: A longitudinal study. Journal of Educational Research, 104(4), 241-252.

Butt, D. S., \& Fiske, D. W. (1968b). Differential correlates of dominance scales. Journal of Personality, 37(3), 415.

Cattell, R. B., Cattell, A. K. S., \& Cattell, H. E. P. (1997). Šestnáctifaktorový osobnostní dotazník: páté vydání. Brno: Psychodiagnostika.

Elias, H., Noordin, N., \& Mahyuddin, R. H. (2010). Achievement motivation and self-efficacy in relation to adjustment among university students. Journal of Social Sciences, 6(3): 333-339

Hills, D. A. (1985). Prediction of effectiveness in leaderless group discussions with the adjective check- list. Journal of Applied Social Psychology, 15, 443-447.

Hoskovcová, S., \& Vybíralová, A. (2011). Příručka BIP - Bochumský osobnostní dotazník; Inventár profesních charakteristik osobnosti. (2nd ed.). Testcentrum: Praha.

Judge T. A., \& Remus, I. (2002). Relationship of personality to performance motivation: A metaanalytic review. Journal of Applied Psychology, 87(4), 797-807.

Kirchner, J. (2012). Tendence k vyhledávání mimořádných prožitků. Československá Psychologie, $56(1), 73-84$.

McClelland, D. C., \& Boyatzis, R. E. (1982). Leadership motive pattern and long-term success in management. Journal of Applied Psychology, 67(6), 737-743.

McClelland, D. C. (1987a). Characteristics of successful enterpreneurs. Journal of Creative Behavior, 27, 219-233.

McClelland, D. C. (1987b). Human motivation. Cambridge: Cambridge University Press.

McCormack, L., \& Mellor, D. (2002). The role of personality in leadership: An application of the five-factor model in the Australian military. Military Psychology, 14(3), 179-197.

McCrae, R. R., \& Costa, P. T. (1987). Validation of the 5-factor model of personality across instruments and observers. Journal of Personality and Social Psychology, 52, 81-90.

O'Connor, M., \& Paunonen, S. (2007). Big Five personality predictors of post secondary academic performance. Personality and Individual Differences, 43, 99-990.

Oh, S. (2012). Leadership emergence in autonomous work teams: Who is more willing to lead? Social Behavior \& Personality: An International Journal, 40(9), 1451-1464.

Richardson, M., \& Abraham, Ch. (2009). Conscientiousness and achievement motivation predict performance. European Journal of Personality, 23: 589-605.

Rotter, B. J. (1989). Internal versus external control of reinforcement; A case history of variable. American Psychologist, 45(4), 489 - 493.

Rueb, J. D., \& Foti, R. J. (1990). Self-monitoring, traits, and leader emergence. Paper presented at the 5th annual meeting of the Society for Industrial and Organizational Psychology, Miami, FL.

Rueb, J., Erskine, H. J., \& Foti, R. J. (2008). Intelligence, dominance, masculinity, and selfmonitoring: Predicting leadership emergence in a military setting. Military Psychology, 20(4), 237-252. 
Jan Kuba: Konstruktová validita Bochumského osobnostního dotazníku

Stacey, R. K., David, J. R., Jeewon, Ch., \& Soo, K. K. (2008). An examination of the antecedents of motivation to lead. International Journal of Business Research, 8(5), 113-119.

Urbánek, T. (2000). Strukturální modelování v psychologii. Brno: Pavel Křepela.

Zuckerman, M. (1979): Sensation seeking: Beyond the optimal level of arousal. Hillsdale, New York: Lawrence Erlbaum Associates.

Zuckerman, M. (1994): Behavioral expressions and biosocial bases of sensation seeking. New York: Cambridge University Press 